\title{
An Analysis of Grammatical Errors in the Written Productions of Some Nigerien Senior Secondary School Students
}

\author{
Abdou Maiguero $^{1 *}$, Moussa Tankari ${ }^{1}$, Ayodele Adebayo Allagbé ${ }^{1}$ \\ ${ }^{1}$ Département d'Anglais, Faculté des Lettres et Sciences Humaines (FLSH), Université de Zinder (UZ), Unnamed Road, Zinder, Niger
}

DOI: $10.36348 /$ jaep.2021.v05i03.004 $\quad$ | Received: 02.03.2021 | Accepted: 19.03 .2021 | Published: 22.03 .2021

*Corresponding author: Abdou Maiguero

\section{Abstract}

This paper examines the grammatical errors in the written productions of senior secondary school students in/from Lycée Amadou Kouran Daga (henceforth LAKD), Zinder, Niger. It specifically seeks to describe, identify and classify the grammatical errors with a view to finding out the reasons of their occurrence in the students' writings. The participants of the present study consist of 30 students (14 male and 16 female students) learning English as a foreign language. The data for the investigation were collected by means of an essay writing which required the participants to write a threeparagraph essay on one of the four narrative and descriptive topics provided. The collected data were then analyzed using Error Analysis and the simple descriptive statistics consisting of frequencies and percentages. The analysis revealed a total of 410 grammatical errors in the participants' writing samples ranked by order of frequency and categories as follows: errors on tenses, spelling errors, agreement errors, preposition and article errors, verb errors, use of nouns, and adjectives. The analysis also showed that male participants committed more grammatical errors than their female counterparts. Further, using Surface Strategy Taxonomy, the findings revealed that the participants committed all the four types of grammatical error. Misformation errors were the most dominant type, followed by omission errors, addition errors, and misodering errors.

Keywords: Analysis, grammatical errors, written productions, high school students, LAKD.

Copyright (C) 2021 The Author(s): This is an open-access article distributed under the terms of the Creative Commons Attribution 4.0 International License (CC BY-NC 4.0) which permits unrestricted use, distribution, and reproduction in any medium for non-commercial use provided the original author and source are credited.

\section{INTRODUCTION}

Writing, one of the four basic language skills, is an important but challenging skill for EFL learners. It constitutes the communicative framework, the medium by which people can share their ideas, feelings, or thoughts with others $[1,2]$. Writing is an important skill for secondary students to know and use because it has a number of pedagogical purposes which, according to Byrne [3] and Harmer [4], include:

- Strengthening the other language skills,

- Enhancing grammatical structures and vocabulary,

- Helping students learn the target language in the classroom.

As a means of enhancing the other language skills, Javed, Juan, \& Nazli [5] note that writing, in relation to a language classroom, assists other language skills such as speaking and reading. It serves as a means of enhancing reading and speaking skills by engaging learners in various activities. For example, writing answers to comprehensions related to a reading passage, summarizing a text after its reading, are activities which involve students in some forms of writing.

Writing at the secondary level is also an important tool in reinforcing learners' performance in grammatical and vocabulary. As Harmer [4] points it out, at secondary school level, writing has always been used as a means to reinforce language that has been taught. For example, students are often asked to write sentences using recently learned grammar for the purpose of practicing it better. Reimes [6] and Hedge [7] cited in Alfaki [8], are also of the view that, in the English language classroom, writing is generally undertaken as an aid to consolidate the learning of new grammatical structures and new lexical items. Helping students learn the target language is another pedagogical purpose of writing in secondary schools. In relation to this, Byrne [3] argues that introducing students to some forms of writing and having them practice them, is a way of providing them with different learning styles and needs. He further adds that allowing students to write in the target language can help them to 
Abdou Maiguero et al., J Adv Educ Philos, Mar, 2021; 5(3): 79-85

retain better than when they are only exposed to the oral medium.

In view of the above-mentioned relevance of writing skill, adequate writing ability is important for every student to have. However, effective writing requires a good knowledge of grammar. Grammar knowledge is very important and even indispensable for students because without it, accurate and fluent use of language in both spoken and written forms is impossible [9-12]. Grammar, as opined by Alexander [13], is the support system of communication. Without the knowledge of grammar rules, one cannot speak or write correctly. Words cannot be used properly in English unless one knows how these words are arranged according to the rules of grammar. Grammar guides how language should be written and spoken [11]. The foregoing accords with Fontaine [14] who states that "without a firm understanding of the grammar of language or how language is structured', it is nearly impossible to write or speak well.

Writing skill as previously stated is an important ability for students to have. Good writing is, however, a difficult skill for EFL students because it requires students to have competence in grammar. In Niger, it is sad to observe that after six years of intensive grammar learning, most of the high secondary school students are unable to write paragraphs with grammatically correct sentences. The purpose of the present study is to analyze some grammatical errors that high secondary school students in LAKD Zinder, Niger, experience in their written productions. It aims at identifying and classifying the grammatical errors that these students commit when writing in order to find out their nature. More specifically, this study seeks to:

1. Describe, identify and classify the grammatical errors committed by senior secondary school students in LAKD, Zinder,

2. Compare the frequency occurrence of errors made by male and female students in LAKD, in their writings.

3. Find out the reasons of the occurrence of the grammatical errors in the writings of the students.

In order to achieve the above stated objectives, the study seeks to answer the four following research questions:

1. What grammatical errors are found in the participants' pieces of writing?

2. How do male participants compare with their female counterparts in terms of grammatical errors?

3. What types of grammatical errors do participants commit when writing in English?

4. Why do participants commit such grammatical errors in their written productions?

\section{LITERATURE REVIEW}

Grammatical problems that EFL students experience when writing in English are a widely studied topic. Many studies carried out by both linguists and educators have dealt with it. Studies investigating students' grammatical problems include that of Singh, Singh, Abd Razak \& Ravinthar [15] who examined grammar errors made by 144 ESL Malay students when writing in English. Their objective was to identify the grammatical errors that the students commit in their writings. They collected their data by means of an essay test and analyzed them using context analysis. The findings showed that the students committed errors in many aspects of grammar. These include errors in subject- verb agreement $(34.70 \%)$, followed by verb tense errors $(30.40 \%)$; noun errors $(19 \%)$; preposition errors $(05.90 \%)$ and adjectives errors $(04.50 \%)$. The least committed errors were on articles, adverbs, and conjunctions which account for (05.50\%). As recommendations, the researchers suggested that teachers should modify their teaching strategies by integrating grammar into writing instruction. This will help in enhancing their students' writing ability.

Kumala, Aimah, \& Ifadah [16] analyzed the writings of 27 students. These scholars aimed to identify and describe the types of grammatical error students make in their written productions. Their data were collected through questionnaires, interviews, and an essay test. The results of the investigation showed that 810 errors were committed by the participants. These were divided into omission errors (37\%) followed by addition errors $(31 \%)$. Errors in misformation were third with a rate of $(30 \%)$ and the lowest in misordering with a figure of $(2 \%)$.

Sadiah \& Royani [17] also carried out a study to investigate errors in grammar that EFL students commit in their writings. Twenty three (23) seventh grade students participated in the study. The researchers used an essay test which required the students to write a descriptive paragraph to collect their data. They also employed a qualitative descriptive method to analyze the data. The findings revealed that the students mostly committed errors in verb agreement $(41 \%)$, pronoun $(18 \%)$, usage $(15 \%)$, sentence pattern $(12 \%)$, spelling $(9 \%)$, and many other grammatical items. The researchers recommended that the students should learn more about English grammar. In addition, teachers should focus on the areas where students make the most errors in in their writings, when teaching.

Goldsmith \& Sujaritjan's paper [18] is another relevant study which examined the grammatical errors in the writing of EFL students. This study involved 68 undergraduate Thai students who were asked to write narrative and descriptive paragraphs. The data were analyzed using descriptive statistics: percentages mean scores and standard deviations. The analysis revealed a total of 2131 grammatical errors committed by the 
Abdou Maiguero et al., J Adv Educ Philos, Mar, 2021; 5(3): 79-85

students in their writings. The most frequent errors were verbs (227), articles (191), and prepositions (178). Errors in tenses, pronouns, spelling, conjunction, punctuation and capitalization have also been significantly made by the students. The study also revealed that grammatical errors made by the female students $(16.84 \%)$ were significantly higher than grammatical errors made by the male students $(10.85 \%)$.

The above reviewed studies are relevant to the present study because they all focus on the common grammatical errors ESL/EFL students at different levels of education commit when they write in English. The review also reveals that:

i. Subject-verb agreement, tenses, pronouns and articles are the major areas in grammar where students commit errors;

ii. The main causes of grammatical errors are due to the students' ignorance of the rules regarding some aspects of grammar and the teachers' inappropriate teaching styles.

iii. Problems experienced by students, especially those who do not speak English as first/second language need to be addressed with much more attention.

\section{METHODOLOGY}

In this section, we describe the methodology drawn on in this study. This includes how data were collected, the participants involved, the instrument used and the data analysis procedure.

\section{Participants}

The participants of this study consist of 30 conveniently selected senior secondary schools students from Lycée Amadou Kouran Daga (LAKD) Zinder, enrolled for the academic year 2019-2020. They are between 19 to 20 years old and have been exposed to the English language for 6 years. The table below highlights the participants' profile by gender.

Table-1: Participants Characteristics by Gender

\begin{tabular}{|l|l|l|}
\hline Gender & Number of Participants & Percentage \\
\hline Male & 14 & 46.67 \\
\hline Female & 16 & 53.33 \\
\hline Total & 30 & 100 \\
\hline
\end{tabular}

\section{Instrument}

The instrument used to collect data in this study comprises an essay test with four (4) different topics. The students are required to choose one of the topics below.

1. 'Tell us what your brother/sister does every morning before leaving to school'.

2. 'Describe an important event that happened in your school last year.

3. 'What do you like to do after your studies, why?
4. Name two countries in the world you like to visit, why?

\section{Data Analysis Procedure}

Simple descriptive statistics including frequencies and percentages was used to analyze the collected data in this study. Tables are drawn to classify the different types of grammatical error EFL students committed and show their frequencies and percentages.

\section{PRESENTATION OF THE RESULTS AND DISCUSSION}

Research Question 1: What grammatical errors are found in the writing of senior secondary school students in/from LAKD, Zinder?

Table-2: Frequency Distribution of Grammatical Errors Found in the Participants' Writing Samples

\begin{tabular}{|l|l|l|l|}
\hline Rank & Item & Frequency & Percentage \\
\hline 1 & Tense & 139 & 33.90 \\
\hline 2 & Spelling & 102 & 24.88 \\
\hline 3 & Agreement & 61 & 14.88 \\
\hline 4 & Preposition & 28 & 6.83 \\
\hline 5 & Article & 28 & 6.83 \\
\hline 6 & Verb & 22 & 5.36 \\
\hline 7 & Noun & 15 & 3.66 \\
\hline 8 & Adjective & 15 & 3.66 \\
\hline Total & & 410 & 100 \\
\hline
\end{tabular}

As outlined in Table-2 above, 410 grammatical errors have been identified in the writing samples of the students overall. The highest errors in frequency are noted in the use of tenses $(n=139$ or $33.90 \%)$. These are followed by spelling errors $(n=102$ or $24.87 \%$ ), and agreement errors ( $\mathrm{n}=61$ or $14.87 \%$ ) of the total. Preposition, article, verb, noun, and adjective errors, respectively accounting for 28 instances or $6.82 \%, 22(5.36 \%), 15(3.65 \%)$, and $15(3.65 \%)$ are the least frequent errors found in the writing samples of the participants.

According to the results, tense errors representing $33.90 \%$ of the total errors made are the most difficult components of the English grammar. This observation is in line with Sukasame, Kantho, \& Narrot [19] and Nforbi \& Siéwoué [20] whose findings also revealed the students' inability to correctly use the English tenses in the tasks assigned to them. Some misuses of tenses in the writing of the students include:

1. *In conclusion I have tell. ( I have told)

2. *I have visit. (I have visited)

3. *It has change a lot. (it has changed)

4. *the country who was dirige. ( the country which was led/governed/directed)

5. *Corona has died the much people in the country this year. (Many people have died of Corona in the country this year/Corona has caused the death of many people in the country this year.) 
Most of the identified tense errors are due to the wrong formation of some tenses. One of the difficulties with composite tenses, as pointed out by Decapua [21], is that EFL students do not know that when the auxiliary verb 'have' combines with the main verb, the past participle is always required. The students' inability to use the English tenses in this study is or can be surprising because tenses are intensively taught and reviewed at all levels of education every year. But this should not be surprising at all in that most EFL teachers are reported to teach tenses ex nihilo or mechanically.

Spelling errors are the second highly ranked errors in this study ( $n=102$ or $25.50 \%$ ). Spelling errors in this study include, but not limited to, the following: contry (country); Macca, Makkah, Meck, (Mecca); familly (family); developpement (development), produits (products). The plausible reasons behind these spelling errors are the interference of both the French language and the students' mother tongue. '*Macca', and '*Makkah' instead of Mecca frequently found in the students' compositions are the results of the influence of the students' mother tongue. The participants who are mostly Hausa speakers use *Macca, *Makkah because it is the word used for Mecca in their first language. Words such as *Meck *familly *devellopement and *produits, used respectively for 'Mecca', 'family', 'development', and 'products' are due to the influence of the French language which is the second language and the language of instruction in Niger. The spelling *contry (country) which was also frequent in the writings of the students could be the result of some teachers' lack of training, pronouncing the word 'country' as if they were pronouncing it in the French language.

Agreement errors rank third in the written productions of the students. Instances of agreement errors found include:

1. *Everybody choose the best average for build his future. (Everybody chooses ...).

2. * She prepare good and delicious meal for all the family. (She prepares ...).
3. *I wish to respect my husband and her family. (I wish to respect my husband and his family).

4. *Two countries whom I want to visit. (Two countries which I want to visit).

5. *I will see many space whom I don't tell you. (I will visit many spaces which I will not tell you).

The major agreement errors committed by the students were on agreement between the verb and its subject as highlighted by erroneous sentences 1 and 2 above. This shows similarities with studies by Mbau, Marhum, \& Muhsin [22], Singh et al., [15] and Sadiah, Royani [17], whose results revealed that most errors made by the students related to subject-verb agreement. The analysis also showed many disagreements between pronouns and their antecedents as illustrated in examples 3, 4, and 5, which could be the result of incomplete rules application [23, 24].

Errors in preposition, articles, verb forms, nouns and adjectives which are less frequent compared to tense, spelling and agreement errors in this study were mostly concerned with cases of omissions, additions or misformations. Examples of such errors are provided in the answer to Research Question 3 in this study.

Research Question 2: How do male participants compare with their female counterparts in terms of grammatical errors?

The results for this research question reveal that male participants significantly made more errors in their writings $(\mathrm{n}=236$ or $57.56 \%)$ than female participants $(n=174$ or $42.43 \%)$. The possible reason for the difference is that female students are generally more concentrated in class than male students. This could help them retain the learnt grammatical rules and use them better than male students. This is, however, in contrast with the findings of a study by Goldsmith \& and Sujaritjan (2020) which revealed that grammatical errors made by the female students were significantly higher than grammatical errors made by the male students. Table-3 below summarizes the key findings.

Table-3: Frequency Distribution of Grammatical Errors by Gender

\begin{tabular}{|l|l|l|l|}
\hline Gender & Number of Participants & Frequency of errors & Percentage \\
\hline Male & 14 & 236 & 57.56 \\
\hline Female & 16 & 174 & 42.44 \\
\hline Total & 30 & 410 & 100 \\
\hline
\end{tabular}

Research Question 3: What types of grammatical error do participants commit when writing in English?

After analysis, the results for Research Question 3 reveal that the highest error types as shown in Table-4 below are misformation errors ( $n=197$ or $48.07 \%$ ), followed by omission errors ( $n=101$ or $24.63 \%)$. Addition errors rank third ( $n=63$ or $15.36 \%$ ) and misordering errors ( $n=19$ or $4.63 \%$ ) come last in terms of the different types of grammatical error committed by the participants in their writings.

\section{Misformation Errors}

These are characterized by the wrong/incorrect use of a morpheme (or word form) or structure [25]. Misformation is the highest type of errors in the 
Abdou Maiguero et al., J Adv Educ Philos, Mar, 2021; 5(3): 79-85

compositions of the students under study. Examples of misformation errors in this study include:

1. *I like to be a doctor for save the people. (I like to be a doctor to save people/ for saving people.).

2. *I like to visited their big hostel. (I like to visit their big hotels.).

3. *I want to built a house ... (I want to build a house ...).

4. *I will vend the car. (I will sell some cars.).

5. *Today you country is many problems. (Today, our/my country has/faces many problems or Today, there are many problems in my/our country.).

The examples above show that the participants have problems in selecting the right word forms when writing. They fail, for example, to use the correct form of verbs after a preposition (example 1), or forget that after verbs such as like or want, the infinitive (to + base form) is needed (examples $2 \& 3$ ). Another striking problem these students face is that they tend to use French words when they are unable to supply the right English word (example 4). The possible reasons accounting for these misformations are attributable to the misapplication of some English grammar rules and communication strategy. Abisamra cited in Ahamed [26] asserts that when learners do not know how to express something in the foreign language, they refer directly to their previously learnt language.

\section{Omission}

Omission is the second type of grammatical error mostly committed by the students in the present study. Omission occurs when a necessary item is left out [25]. Examples of omissions found in the participants' writings are:

1. * If I giving the opportunity to visit Meka. (If I am given the opportunity to visit Mecca).

2. *I want go Meckah. (I want to go to Mecca.).

3. *I like this country very and very. (I like this country a lot/so much.).

4. *I like do many because I want to built myself family. (I like to do many things because I want to build a house for my own family.).

5. *All the student ... (All the students ...).

Most of the omissions as illustrated in sentences 2 and 4 are preposition omissions. The reason is that selecting good/appropriate prepositions has always been challenging for foreign language learners. However, omissions such as those in sentences 4 and 5 could be attributed to the students' carelessness.

\section{Addition}

Addition involves the insertion of an item which is not needed in an utterance, as illustrated in the following sentences by the participants:
1. *I like to marry and have many childrens. (I like to get married and have many children.)

2. *I will go the Nigeria. (I will go to Nigeria.).

3. *Because my brother it is in Nigeria ... (Because my brother is in Nigeria ...).

4. *America is the a good place for the students. (America is a good place for students.).

5. *My sisters leaving in the every morning. (My sisters leave to school every morning.).

The above errors of additions which mostly involve the insertion of articles are neither due to the influence of the mother tongue nor the influence of the French language. The main cause for the occurrence of such errors may result from the students' lack of knowledge regarding the use of articles in English.

\section{Misordering}

The least type of errors committed by the students in their writing is misordering with only 19 cases $(4.63 \%)$. There is misordering when a morpheme or a group of morphemes is misplaced within an utterance [23, 27]. The following sentences and expresions are instances of misordering errors found in the written productions of the students:

1. * Before the time of school. (Before school time).

2. *I prepare the uniform school. (I get my school uniform ready).

3. *I want to be a woman sage. (I want to be a midwife.).

4. *She gets her study bag. (She gets her school bag.).

5. *It is a country rich. (It is a rich country.).

It must be noted at this stage that most of the misordering errors committed by the students in this study are due to the direct translation of the French language or the students' first language. It must be noted too that most of the errors committed by the participants are global errors Burt, Dulay \& Krashen as cited in James [23]. Global errors are errors which are difficult to process because they violate the overall structure of the sentence and affect communication [28, 24]. Instances of global errors in the writings of the students include:

1. I wish to flotte ours lifes.

2. *the Meck at the population at Meck is beautiful because the schopp, the immeable the tarred.

3. *I your give the eating.

As it appears, it is very hard for the reader to understand and interpret the meaning the writers intend to convey in the above sentences. 
Table-4: Frequency Distribution of Errors by Surface Strategy Taxonomy

\begin{tabular}{|l|l|l|l|}
\hline S/N & Item & Frequency & Percentage \\
\hline 1 & addition & 63 & 15.37 \\
\hline 2 & omission & 101 & 24.63 \\
\hline 3 & misformation & 197 & 48.05 \\
\hline 4 & misordering & 19 & 4.63 \\
\hline 5 & others & 30 & 7.32 \\
\hline Total & & 410 & 100 \\
\hline
\end{tabular}

\section{CONCLUSION AND \\ RECOMMENDATIONS}

This study has examined the grammatical errors in the writings of senior secondary school in/from LAKD, Zinder, Niger. It has specifically sought to describe, identify and classify the grammatical errors with a view to finding out the reasons of their occurrence in the students' writings. The results show that these students encounter problems in using many aspects of grammar. These include tenses, spelling, agreement, prepositions, articles, verbs, nouns and adjectives. The results also exude that male participants committed more errors in their writing than their female counterparts. The possible reason for this is that female students are generally more concentrated in class than male students.

Further, the results reveal that the participants committed addition, omission, misformation, and misordering errors in their written productions. Misformations were the highest type of errors followed by omissions, additions, and misordering. Other errors which could not be categorized as misformations, omissions, additions, or misordering were also found in the writings of the students. The reasons of the recurrence of errors in the writings of the students were mostly interlingual and intralingual. However, most of the committed errors were the result of the interference of the French language which is the official and language of instruction in the country.

Based on the above-mentioned results, it is recommended that:

1. EFL teachers should change their teaching methods, strategies and styles; most (not to say all) EFL teachers in Niger still apply traditional methods in teaching English structures. By so doing, they do not provide their students with a real-life conversational context for these students to use these structures communicatively.

2. They should also make students practice new grammatical structures communicatively, not mechanically.

3. Textbook writers should provide activities which could help students to use the English language in a more communicative way.
4. Students should abide by grammatical rules and avoid transferring the structures of their mother tongue or those of the French language when writing in English.

\section{REFERENCES}

1. Domantay, M., D., D., \& Ramos, L., Q. (2018). English writing performance of grade 11 students. In Journal of Advanced Studies, 1(1), 1-19.

2. Indrilla, N. (2018). The effectiveness of scientific approach and contextual teaching and learning approach in teaching writing. Lingua Cultura, 12(4),405-413. Doi: 10.21512/lc.v12i4.

3. Byrne, D. (1993). Teaching Writing Skills. Longman Group Limited: Essex CM202JE, England.

4. Harmer, J. (2004). How to teach writing. Essex CM202JE: Pearson Education.

5. Javed, M., Juan, W., X., \& Nazli, S. (2013). A study of students' assessment in writing skills of the English language. International Journal of Instruction, 6(2), 129-144.

6. Ratkowitsch, C. (1993). Das Grab des Propheten: Die Mohammed-Dichtungen des Embricho von Mainz und Walter von Compiègne. Wiener Studien, 106, 223-256.

7. Hedge, S. G., Ratnasamy, P., Kustov, L. M., \& Kazansky, V. B. (1988). Acidity and catalytic activity of SAPO-5 and AlPO-5 molecular sieves. Zeolites, 8(2), 137-141.

8. Alfaki, I. M. (2015). University students' English writing problems: Diagnosis and remedy. International Journal of English Language and Teaching, 3(3), 40-52. Retrieved January 15, 2021 from www.eajournals.org.

9. Larsen-Freeman, D. (2015). Research into practice: Grammar learning and teaching. Language Teaching, 48(2), 263-280. Doi: 10.1017/SO26144814000408

10. Swick, E. (2005). English grammar for ESL learners. New York: McGraw-Hill. Doi: $10.1036 / 00714653559$.

11. Wang, S. (2010). The significance of English grammar to middle school students in China. Journal of Language Teaching and Research, 1(3), 13-319.

12. Dkhissi, Y. (2014). An integrative model grammar teaching from academic to communicative needs. 
Abdou Maiguero et al., J Adv Educ Philos, Mar, 2021; 5(3): 79-85

International Journal of Language and Linguistics, 2(3), 145-153. Doi:10.11648/j.ijll,2014 023-13.

13. Alexander, L. G. (2003). Longman English Grammar. Pearson Education. Essex: England.

14. Fontaine, L. (2013). Analysing English grammar: A systemic functional introduction $1^{\text {st }}$ edition. New-York: Cambridge University Press.

15. Singh, C. K. S., Singh, A. K. J., Abd Razak, N. Q., \& Rainthar, T. (2017). Grammar errors made by ESL tertiary students in writing. English Language Teaching, 10(5), 16-27. Doi: 10.5539/elt.v10n5p16.

16. Kumala, B. P., Aimah, S., \& Ifadah, M. (2018). An analysis of grammatical errors on students' writing. $2^{\text {nd }}$ English Language and Literature International Conference (ELLiC) ProcedingsELLiC Procedings, 2, 144-149.

17. Sadiah, S., \& Royani, S. A. (2019). An analysis of grammatical errors in students' writing descriptive text. Professional Journal of English Education, 2(6), pp. 764-770.

18. Goldsmith, A., \& Sujararitjan, P. (2020). An analysis of grammatical errors made by $3^{\text {rd }}$ year Thai Business English undergraduates when spontaneously writing narrative and descriptive paragraphs. International Journal of Research, 8,75-95. Doi:https://doi.org/10.29121.

19. Sukasame, N., Kantho, S., \& Narrot, P. (2014). A study of errors in learning English grammatical structures on tenses of Matthomsuksa students of the Demonstration School, Khinkaren University. In Procedia Social and Behavioral Sciences 116 (2014) 1934-1939. $5^{\text {th }}$ World Conference on Educational Science. Retrieved February $6^{\text {th }}$ ? 2021 from www.sciencedirect.com

20. Nforbi, E., \& Siéwoué, M. B. (2016). Tense and aspect in the era of competence-based English language teaching in Cameroon's secondary schools. International Journal of English Language Teaching, 4(4), 40-54. Retrieved February $4^{\text {th }}, 2021$ from www.eajournals.org.

21. DeCapua, A. (2017). Grammar for teachers. A guide to American English for native and nonnative speakers $2^{\text {nd }}$ ed. Springer International Publishing: New York, USA.

22. Mbau, A. T., Marhum, M., \& Muhsin, M. A. (2014). An analysis on subject-verb agreement errors in writing paragraphs made by the second semester students of English Department. Ejournal of English Language Teaching Society (ELTS), 2(2),1-15. Doi:1022487/j23341841.2014.v2i2.3036.

23. James, C. (2013). Errors in language learning and use: Exploring error analysis. New York: Routledge.

24. Ellis, R. (2003). Second Language Acquisition. Oxford: Oxford University Press.

25. Ellis, R. (1999). The Study of Second Language Acquisition. Oxford, Oxford University Press.

26. Ahamed, F. E. Y. (2016). An investigation of writing errors of Saudi EFL university students. International Journal of Social Science and Humanities Research, 4(2), pp. 189-211. Retrieved January 12, 2021 from www.researchpublish.com

27. Ellis, R., \& Barkhuizen, G. (2009). Analyzing learner language. Oxford: Oxford University Press.

28. Cheng, X. Y. (2015). Interlanguage-based error analysis in high vocational and technological college EFL education in China. Journal of Language Teaching and Research, 6(3), 639-646. DOI: // dx.doi.org/10.17507/jltr.0603.22. 